Supplement of Atmos. Chem. Phys., 15, 5599-5609, 2015

http://www.atmos-chem-phys.net/15/5599/2015/

doi:10.5194/acp-15-5599-2015-supplement

(C) Author(s) 2015. CC Attribution 3.0 License.

(c) (i)

Atmospheric

Chemistry

and Physics

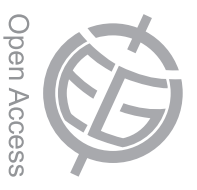

Supplement of

\title{
Iodine observed in new particle formation events in the Arctic atmosphere
} during ACCACIA

\section{J. D. Allan et al.}

Correspondence to: J. D. Allan (james.allan@ manchester.ac.uk)

The copyright of individual parts of the supplement might differ from the CC-BY 3.0 licence. 
Section S1: additional figures

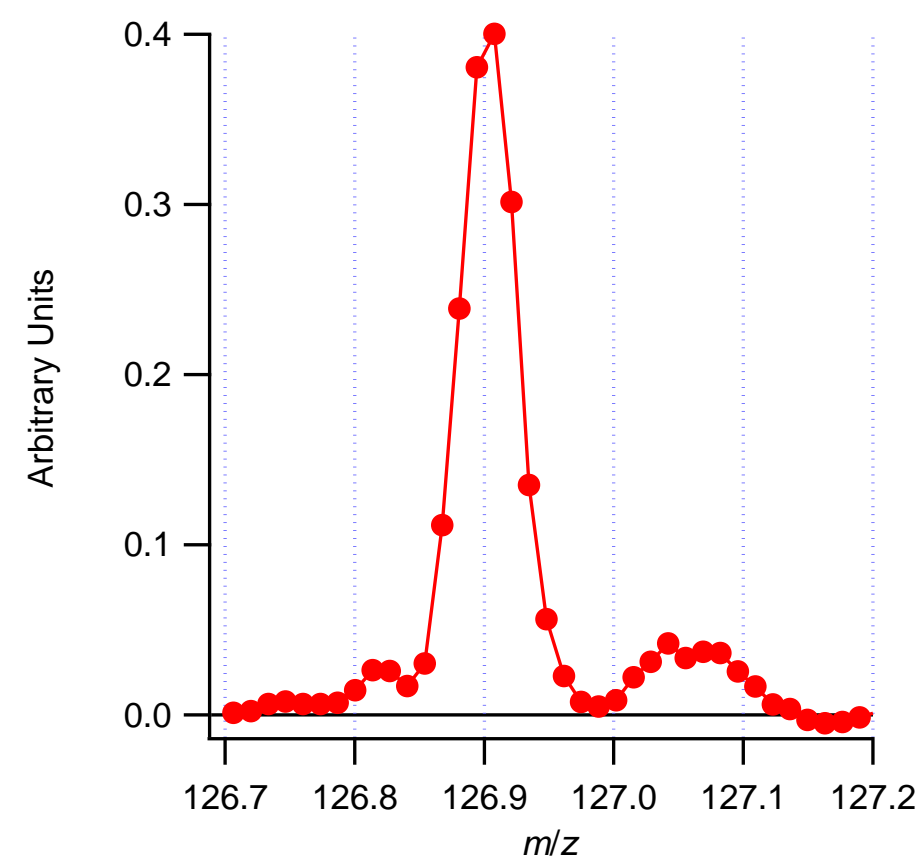

Figure S1.1: Detail of the AMS ' $V$ ' mode peak at $m / z=127$ during the high-iodine event, showing a peak at 126.90, consistent with $\mathrm{I}^{+}$. The second peak could be a combination of $\mathrm{C}_{10} \mathrm{H}_{7}^{+}$(127.05), $\mathrm{C}_{6} \mathrm{O}_{3} \mathrm{H}_{7}^{+}(127.04)$ and $\mathrm{C}_{7} \mathrm{O}_{2} \mathrm{H}_{11}{ }^{+}(127.08)$. 


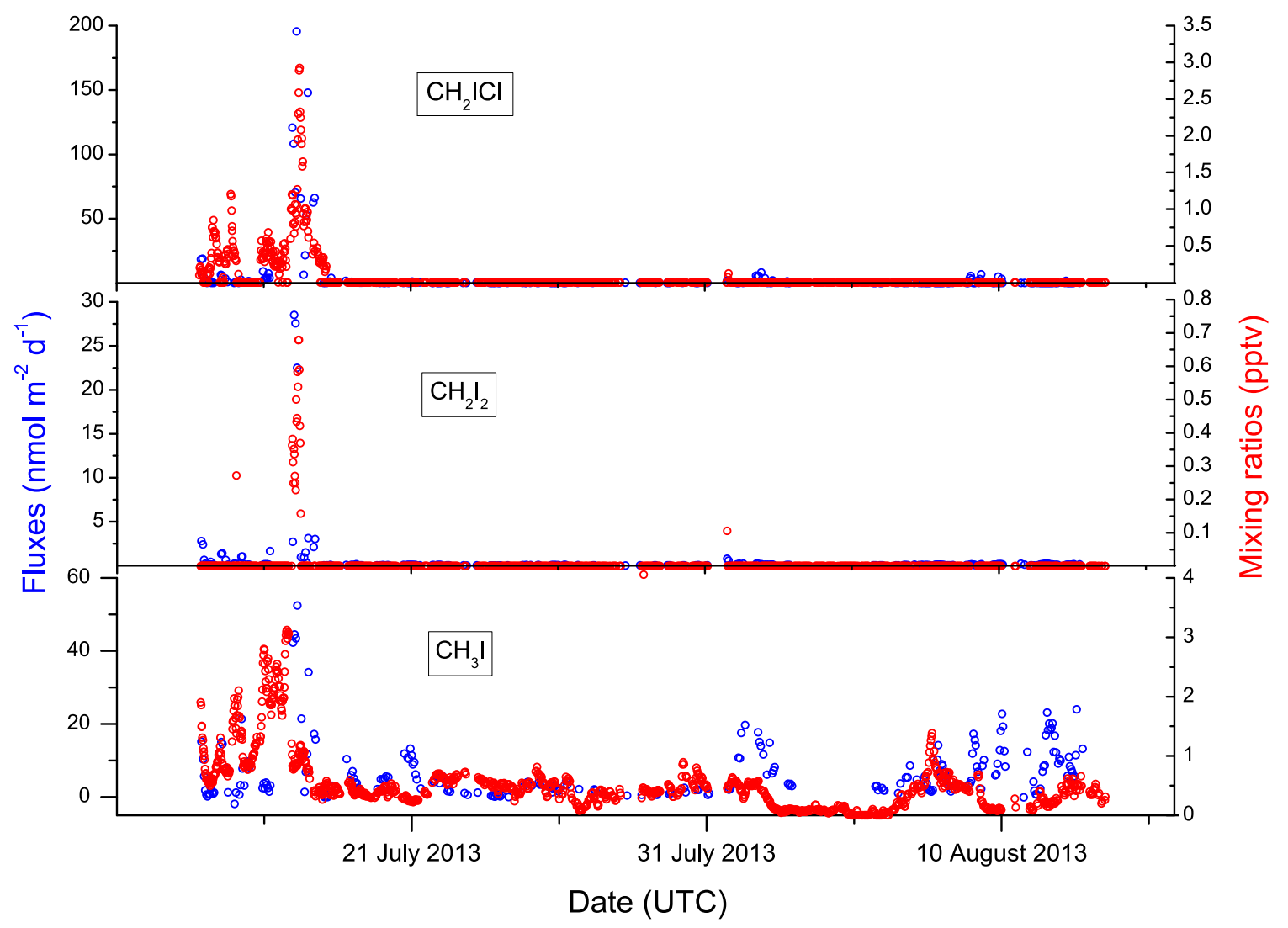

Figure S1.2: Fluxes and concentrations of iodocarbons measured during this study. 


\section{Section S2: AMS Data Processing}

Data were processed using SQUIRREL V1.5E, with the default fragmentation tables (Allan et al., 2004; Aiken et al., 2008), adjusted to remove gas phase interferences at $m / z=16\left(\mathrm{O}^{+}\right)$and $44\left(\mathrm{CO}_{2}{ }^{+}\right)$. Positive Matrix Factorisation (PMF) (Paatero and Tapper, 1994) was performed using PMF2 V4.2 in robust mode and the PET V2.06 toolkit (Ulbrich et al., 2009). The Unit Mass Resolution (UMR) data were used for this, as the High Resolution (HR) data was not reliable at the high $\mathrm{m} / \mathrm{z}$ values of interest here. The data pretreatment steps recommended by Ulbrich et al. (2009) were followed, using the error model of Allan et al. (2003).

PMF converged successfully for a large number of factors, however the 5 -factor solution was deemed the most physically meaningful. The results of this factorisation are shown in figures S2.1 and S2.2. Rotational ambiguity was explored using the FPEAK parameter (Paatero et al., 2002), however nonzero values either yielded unphysical results or failed to converge. While larger numbers of factors (up to 8) converged successfully, these showed evidence of factor 'splitting' and 'mixing' (Ulbrich et al., 2009; Allan et al., 2010), meaning the results were probably not physically meaningful. Regardless, no factor was found that explained the signal at $m / z=127$.

Within the 5 -factor solution, factor 1 is sea salt misattributed as organic matter, evidenced by the peaks at $m / z=58$ and 60 corresponding to $\mathrm{NaCl}^{+}$. While the AMS is not optimised to study sea salt, it can be present in the mass spectra in marine environments (Ovadnevaite et al., 2012). The peaks at the high $\mathrm{m} / \mathrm{z}$ are fragments of tungsten compounds containing various combinations of $\mathrm{O}, \mathrm{H}$ and $\mathrm{Cl}$ atoms, caused by the corrosion of the vaporiser surface (Drewnick et al., 2015). Factors 2 and 3, which are designated aromatics (containing characteristic peaks at $m / z=91$ and 77 ) and hydrocarbon-like organic aerosol (containing aliphatic hydrocarbon series) respectively, can be associated with combustion sources (Canagaratna et al., 2004), specifically the ship's own stack emissions and sources around ports. Factor 4 is methyl sulphonic acid (MSA), evidenced by characteristic peaks such as $m / z=79$ (Phinney et al., 2006). Factor 5 has a characteristic peak at $\mathrm{m} / \mathrm{z}=44\left(\mathrm{CO}_{2}{ }^{+}\right)$, so is probably a highly oxygenated organic aerosol (McFiggans et al., 2005; Jimenez et al., 2009). While this factor does appear to show a degree of covariance with MSA, the exact chemical nature and source of this can only be speculated at.

In all of the convergent solutions up to 8 factors, no factor showed a significant contribution from $\mathrm{m} / \mathrm{z}=127\left(\mathrm{I}^{+}\right)$. Upon inspection of the residuals, a clear signal can be seen associated with the 25-27 July case study. The residual diagnostic data from the 5 -factor solution is presented in Figure S2.3. This implies that the $\mathrm{I}^{+}$signal is not covariant with any of the other factors identified using PMF. The reason it does not form the basis of its own factor is because it does not account for enough overall weighted variance compared to the other factors. While $\mathrm{I}_{2} \mathrm{O}_{5}$ is also known to produce other peaks (e.g. $1 \mathrm{O}^{+}, \mathrm{IO}_{2}{ }^{+}$), these are expected to be much smaller (McFiggans et al., 2004) and no signals were found in their residuals over the noise. Note that while no significant $I^{+}$signal was found in association with the other candidate nucleation events, this does not mean that there was no iodine present; during these other events, not enough particulate mass existed above the sizes detectable by the AMS (>30 nm approx.) (Liu et al., 2007). 


\section{Section S2 figures}

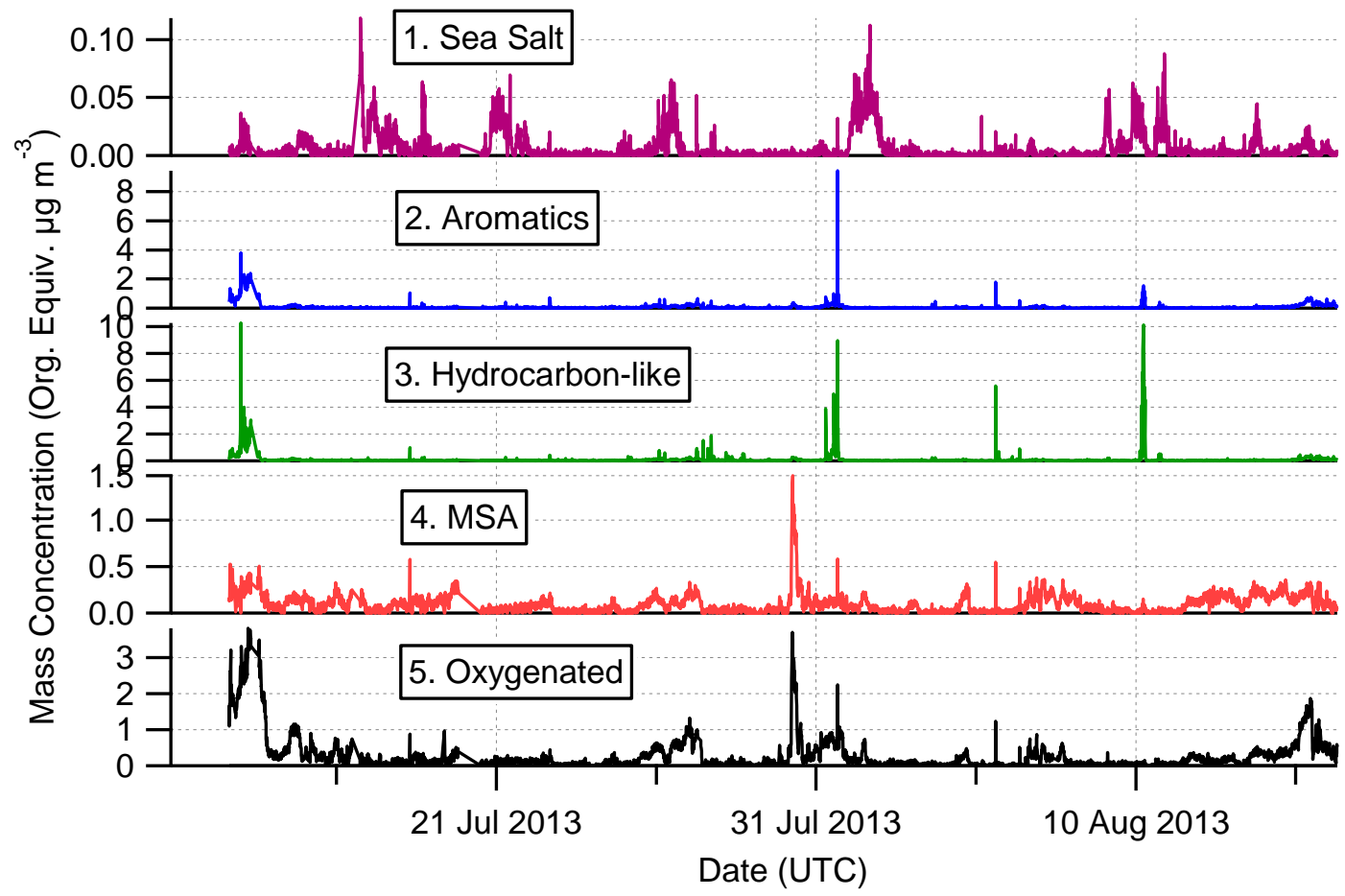

Figure S2.1: Time series of derived factors from the 5-factor PMF solution.

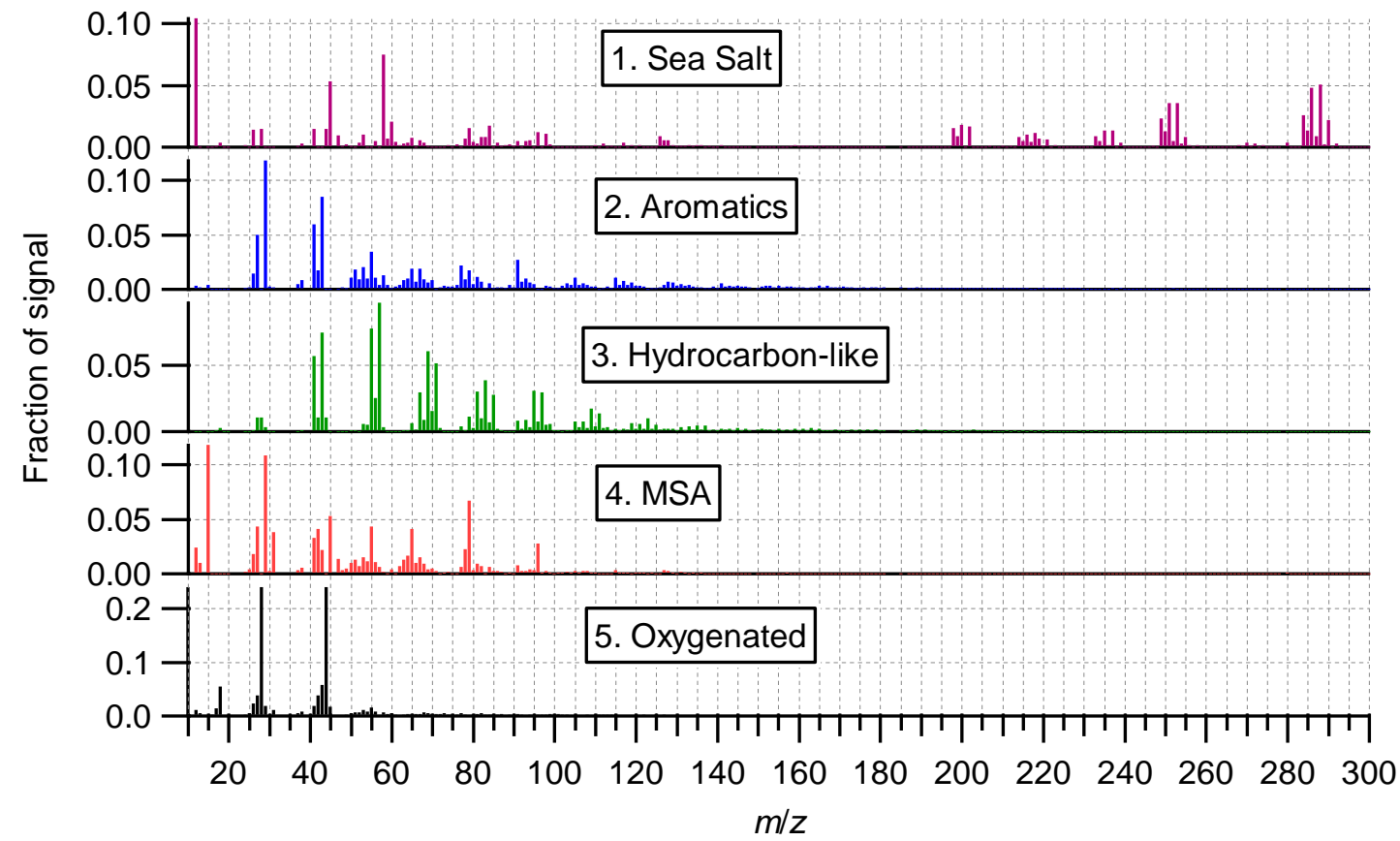

Figure S2.2: Mass spectral profiles of the 5-factor PMF solution. 


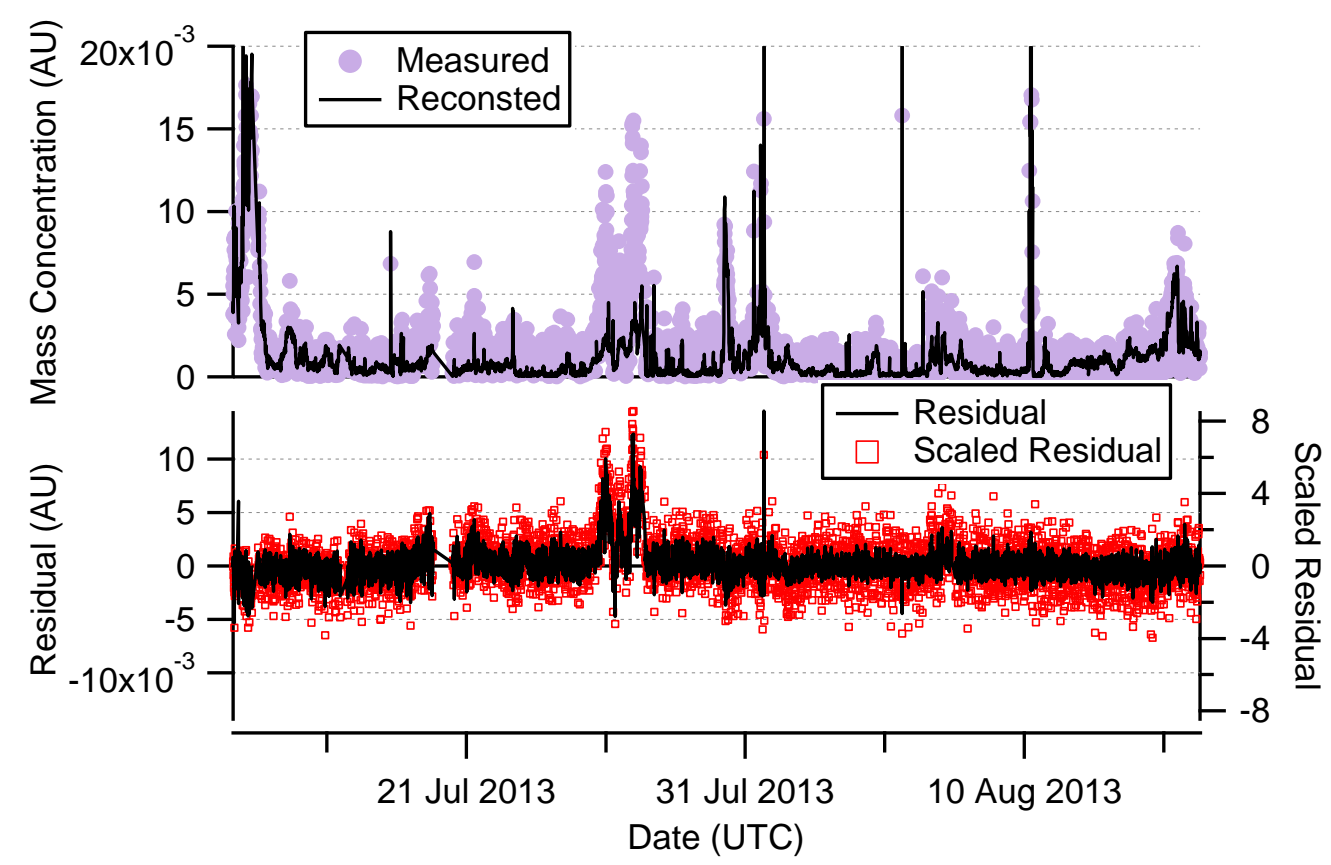

Figure S2.3: Residual diagnostics for $m / z=127\left(\mathrm{I}^{+}\right)$from PMF analysis. The scaled residual is scaled by the modelled error (i.e. the contribution of each datum to the $Q$ statistic).

\section{References:}

Aiken, A. C., Decarlo, P. F., Kroll, J. H., Worsnop, D. R., Huffman, J. A., Docherty, K. S., Ulbrich, I. M., Mohr, C., Kimmel, J. R., Sueper, D., Sun, Y., Zhang, Q., Trimborn, A., Northway, M., Ziemann, P. J., Canagaratna, M. R., Onasch, T. B., Alfarra, M. R., Prevot, A. S. H., Dommen, J., Duplissy, J., Metzger, A., Baltensperger, U., and Jimenez, J. L.: $\mathrm{O} / \mathrm{C}$ and $\mathrm{OM} / \mathrm{OC}$ ratios of primary, secondary, and ambient organic aerosols with high-resolution time-of-flight aerosol mass spectrometry, Environ. Sci. Technol., 42, 4478-4485, 2008.

Allan, J. D., Jimenez, J. L., Williams, P. I., Alfarra, M. R., Bower, K. N., Jayne, J. T., Coe, H., and Worsnop, D. R.: Quantitative sampling using an Aerodyne aerosol mass spectrometer - 1 . Techniques of data interpretation and error analysis, J. Geophys. Res.-Atmos., 108, 4090, doi:10.1029/2002JD002358, 2003.

Allan, J. D., Delia, A. E., Coe, H., Bower, K. N., Alfarra, M. R., Jimenez, J. L., Middlebrook, A. M., Drewnick, F., Onasch, T. B., Canagaratna, M. R., Jayne, J. T., and Worsnop, D. R.: A generalised method for the extraction of chemically resolved mass spectra from aerodyne aerosol mass spectrometer data, J. Aerosol. Sci., 35, 909-922, DOI 10.1016/j.jaerosci.2004.02.007, 2004.

Allan, J. D., Williams, P. I., Morgan, W. T., Martin, C. L., Flynn, M. J., Lee, J., Nemitz, E., Phillips, G. J., Gallagher, M. W., and Coe, H.: Contributions from transport, solid fuel burning and cooking to primary organic aerosols in two UK cities, Atmos. Chem. Phys., 10, 647-668, 2010.

Canagaratna, M. R., Jayne, J. T., Ghertner, D. A., Herndon, S., Shi, Q., Jimenez, J. L., Silva, P. J., Williams, P., Lanni, T., Drewnick, F., Demerjian, K. L., Kolb, C. E., and Worsnop, D. R.: Chase studies of particulate emissions from in-use New York City vehicles, Aerosol Sci. Technol., 38, 555-573, 10.1080/02786820490465504, 2004. 
Drewnick, F., Diesch, J. M., Faber, P., and Borrmann, S.: Aerosol mass spectrometry: particlevaporizer interactions and their consequences for the measurements, Atmos. Meas. Tech. Discuss., 8, 3525-3570, 10.5194/amtd-8-3525-2015, 2015.

Jimenez, J. L., Canagaratna, M. R., Donahue, N. M., Prevot, A. S. H., Zhang, Q., Kroll, J. H., DeCarlo, P. F., Allan, J. D., Coe, H., Ng, N. L., Aiken, A. C., Docherty, K. S., Ulbrich, I. M., Grieshop, A. P., Robinson, A. L., Duplissy, J., Smith, J. D., Wilson, K. R., Lanz, V. A., Hueglin, C., Sun, Y. L., Tian, J., Laaksonen, A., Raatikainen, T., Rautiainen, J., Vaattovaara, P., Ehn, M., Kulmala, M., Tomlinson, J. M., Collins, D. R., Cubison, M. J., Dunlea, E. J., Huffman, J. A., Onasch, T. B., Alfarra, M. R., Williams, P. I., Bower, K., Kondo, Y., Schneider, J., Drewnick, F., Borrmann, S., Weimer, S., Demerjian, K., Salcedo, D., Cottrell, L., Griffin, R., Takami, A., Miyoshi, T., Hatakeyama, S., Shimono, A., Sun, J. Y., Zhang, Y. M., Dzepina, K., Kimmel, J. R., Sueper, D., Jayne, J. T., Herndon, S. C., Trimborn, A. M., Williams, L. R., Wood, E. C., Middlebrook, A. M., Kolb, C. E., Baltensperger, U., and Worsnop, D. R.: Evolution of Organic Aerosols in the Atmosphere, Science, 326, 1525-1529, DOI 10.1126/science.1180353, 2009.

Liu, P. S. K., Deng, R., Smith, K. A., Williams, L. R., Jayne, J. T., Canagaratna, M. R., Moore, K., Onasch, T. B., Worsnop, D. R., and Deshler, T.: Transmission Efficiency of an Aerodynamic Focusing Lens System: Comparison of Model Calculations and Laboratory Measurements for the Aerodyne Aerosol Mass Spectrometer, Aerosol Sci. Technol., 41, 721-733, 10.1080/02786820701422278, 2007.

McFiggans, G., Coe, H., Burgess, R., Allan, J., Cubison, M., Alfarra, M. R., Saunders, R., Saiz-Lopez, A., Plane, J. M. C., Wevill, D. J., Carpenter, L. J., Rickard, A. R., and Monks, P. S.: Direct evidence for coastal iodine particles from Laminaria macroalgae - linkage to emissions of molecular iodine, Atmos. Chem. Phys., 4, 701-713, 2004.

McFiggans, G., Alfarra, M. R., Allan, J., Bower, K., Coe, H., Cubison, M., Topping, D., Williams, P., Decesari, S., Facchini, C., and Fuzzi, S.: Simplification of the representation of the organic component of atmospheric particulates, Faraday Discuss., 130, 341-362, 2005.

Ovadnevaite, J., Ceburnis, D., Canagaratna, M., Berresheim, H., Bialek, J., Martucci, G., Worsnop, D. R., and O'Dowd, C.: On the effect of wind speed on submicron sea salt mass concentrations and source fluxes, J. Geophys. Res.-Atmos., 117, D16201, Doi 10.1029/2011jd017379, 2012.

Paatero, P., and Tapper, U.: Positive matrix factorization: A non-negative factor model with optimal utilization of error estimates of data values, Environmetrics, 5, 111-126, 10.1002/env.3170050203, 1994.

Paatero, P., Hopke, P. K., Song, X. H., and Ramadan, Z.: Understanding and controlling rotations in factor analytic models, Chemometr Intell Lab, 60, 253-264, Doi 10.1016/S0169-7439(01)00200-3, 2002.

Phinney, L., Leaitch, W. R., Lohmann, U., Boudries, H., Worsnop, D. R., Jayne, J. T., Toom-Sauntry, D., Wadleigh, M., Sharma, S., and Shantz, N.: Characterization of the aerosol over the sub-arctic north east Pacific Ocean, Deep-Sea Res. Pt. II, 53, 2410-2433, 10.1016/j.dsr2.2006.05.044, 2006.

Ulbrich, I. M., Canagaratna, M. R., Zhang, Q., Worsnop, D. R., and Jimenez, J. L.: Interpretation of organic components from positive matrix factorization of aerosol mass spectrometric data, Atmos. Chem. Phys., 9, 2891-2918, 2009. 